\title{
HVMANITAS
}

\section{Tebas: a imagem literária do tempo e da história em Mário de Carvalho}

Autor(es): $\quad$ Silva, Maria de Fátima

Publicado por: $\begin{aligned} & \text { Faculdade de Letras da Universidade de Coimbra, Instituto de Estudos } \\ & \text { Clássicos }\end{aligned}$

URL

persistente:

DOI: $\quad$ DOI:http://dx.doi.org/10.14195/2183-1718_62_16

Accessed : $\quad$ 26-Apr-2023 09:59:38

A navegação consulta e descarregamento dos títulos inseridos nas Bibliotecas Digitais UC Digitalis, UC Pombalina e UC Impactum, pressupõem a aceitação plena e sem reservas dos Termos e Condições de Uso destas Bibliotecas Digitais, disponíveis em https://digitalis.uc.pt/pt-pt/termos.

Conforme exposto nos referidos Termos e Condições de Uso, o descarregamento de títulos de acesso restrito requer uma licença válida de autorização devendo o utilizador aceder ao(s) documento(s) a partir de um endereço de IP da instituição detentora da supramencionada licença.

Ao utilizador é apenas permitido o descarregamento para uso pessoal, pelo que o emprego do(s) título(s) descarregado(s) para outro fim, designadamente comercial, carece de autorização do respetivo autor ou editor da obra.

Na medida em que todas as obras da UC Digitalis se encontram protegidas pelo Código do Direito de Autor e Direitos Conexos e demais legislação aplicável, toda a cópia, parcial ou total, deste documento, nos casos em que é legalmente admitida, deverá conter ou fazer-se acompanhar por este aviso. 
humanitas

Vol. LXII

2010 


\title{
TEBAS. A IMAGEM LITERÁRIA DO TEMPO E DA HISTÓRIA EM MÁRIO DE CARVALHO
}

\author{
Maria de Fátima Silva \\ Universidade de Coimbra
}

O VER TEBAS - Não curar de a procurar, pois é sita nas regiões que quanto mais procuradas tanto menos encontradas.

Mas ainda que em qualquer volta dos caminhos cimeiros se adregue vislumbrar ao longe, entre bruma cinzenta, suas muralhas gris, repletas de foscas armaduras, e se logre penetrar o interior dos muros, não se iluda homem sobre o ficar quite de cuidados, pois outros e bem pesarosos na altura lhe virão.

M. de Carvalho, O livro grande de Tebas, Navio e Mariana, 112¹.

\section{Resumo}

No seu Livro grande de Tebas, M. de Carvalho retoma um símbolo forte da antiguidade clássica para reflectir sobre Tempo e História. Criar a sua própria Tebas é o grande desafio que se propõe. Cumpre-o associando à experiência profissional de um arquivista o talento de um criador. Porque só esta combinação permite recuperar, para além da História objectiva, a verdadeira biografia da Humanidade.

Palavras chave: Mário de Carvalho, história, ficção.

\section{Abstract}

In his book O livro grande de Tebas (The great book of Thebes), Mário de Carvalho insists on a classical reference able to express time and history. His aim is to imagine his own Thebes, by putting together the professional experience of an archivist and the talent of a creator. This is the only combination that permits the recuperation, besides History, of the true biography of Man.

Key-words: Mário de Carvalho, history, fiction.

1 331996, Lisboa, Caminho. 
Esta é talvez a melhor síntese da proposta para que M. de Carvalho convida o seu leitor, de uma viagem através do Tempo e da História. Tebas remete para um destino - o seu passado ou a identidade de si mesmo - não escolhido mas que se impõe, para onde os passos do espírito se dirigem sem preconceitos, apenas como para algo que está implícito na ininterrupta cadeia humana. Mas se inevitável, esta é também uma marcha condenada à frustração. É a tradição que lhe serve de arranque e de guia. Foi ela a construtora, em linhas difusas, de uma cidadela, aquela onde toda a imaginação humana conflui como seu último ascendente. Ver Tebas seria, para cada um de nós, ver-se a si próprio, perceber o mundo onde, como homem, desde sempre existiu. Mas o que essa "pátria" oferece é uma imagem de "bruma", de distância e de esbatimento, longínqua demais para ser penetrada e conhecida. Vê-la é mais colher dúvidas que certezas.

Se aos antigos Gregos - para quem o nome de Tebas imediatamente remete - fosse perguntada a identidade de um guia capaz de os conduzir em idêntica aventura de devassar a História, a resposta não poderia ser senão esta: os poetas, em cuja tradição se filiaram os primeiros historiadores. São eles, uns e outros espíritos tocados pelas Musas e capazes de "palavras doces como o mel", os relatores, em tons diversos, da "biografia da Humanidade" 2 . E essa não se faz apenas de relatos concretos, deste ou daquele episódio, com data, lugar e agentes específicos. Somados, os episódios que estabeleceram momentos definidos no fluir da História permitem deduzir traços gerais, chegar a Tebas como a Pátria de toda a Humanidade (p. 20) ${ }^{3}$ : "Era agora como se me houvesse uma pátria desimpedida, disponível, a que eu poderia chamar $a$ Pátria"4.

E para M. de Carvalho quem é esse sujeito, que protagoniza a grande odisseia de viajar pelo Tempo e pela História? É o autor que vive rodeado

2 Esta é uma expressão de Immerwahr, H. R. (1966), Form and thought in Herodotus. University of North Carolina: 4, a propósito do que chama "os aspectos não científicos da História". Sobre esta disciplina, o mesmo autor pode afirmar: "Não se trata apenas de uma construção racional baseada em testemunhos, mas, muito para além disso, de uma memória colectiva, em que o homem obtém autoconhecimento pela contemplação do passado".

3 As páginas citadas, salvo outra identificação, remetem para a edição supracitada de $O$ livro grande de Tebas.

4 Seria interessante recordar os três níveis que também Immerwahr, 1966: 6 estabelece para o entendimento de Heródoto sobre o que seja, na sua experiência, uma ainda incipiente história: factos, tradições a respeito dos mesmos factos, e o trabalho historiográfico para interpretar essas tradições. É dentro de um plano semelhante que M. de Carvalho se move nesta sua obra. 
de livros, que, diariamente, se cerca de "rimas de infólios e resmas de velhos manuscritos tisnados", isolado, da luz crua que banha a realidade imediata, pelas paredes protectoras de uma qualquer biblioteca. Trata-se do amante da História, do navegador do passado, do explorador da sua própria identidade enquanto Homem. Para o seu projecto há um ponto de partida, o que um registo material estabelece como carta de marinharia sobre que constrói o seu roteiro. É preciso, antes de mais, criar com o passado uma familiaridade, para que então surja "o chamamento". Esta é a centelha - qual toque das Musas - que introduz a diferença essencial com o que é o manusear diário, automático, profissional de testemunhos mais ou menos objectivos - "as minhas mil e tantas páginas de notas, os grossos volumes à margem glosados, os mil manuscritos encardidos, já meio decifrados e comentados", p. 19 -, que se abandonam, em demanda de uma nova etapa, que não se faz sem a primeira, mas sem a qual "livros, certidões, documentos de papel, de pergaminho e de pedra" mais não são do que uma "rotina, que apenas perfazia um labor que encomendado me tinham".

Cumprido este prólogo, M. de Carvalho envereda por um percurso literário muito do seu gosto: o desmontar da normalidade em busca da liberdade de pensamento e de um projecto para uma vida autêntica ${ }^{5}$. Manusear documentos é, no caso concreto deste romance, o padrão de um trabalho mecanizado, imposto pela convenção social, dobrado ao nomos, a que urge escapar, sob pena de se ver liquidado o talento e aniquilada uma verdadeira capacidade especulativa, de que cada criatura humana é, de acordo com a sua physis, dotada. Não é este o sentido de História que o verdadeiro intelectual procura, recusando a atitude de um simples amanuense para assumir a de um verdadeiro criador. Para isso há que abandonar a História livresca, à procura de ver e sentir, verdadeiramente, o passado.

Foi com entusiasmo interior, sentindo-se rodeado de sorrisos de aplauso, que o aventureiro se lançou em imprevisível odisseia, em busca do que se pôde chamar "a total lembrança das origens de mim", um conglomerado de referências, sem espaço nem tempo determinados, que constitui a essência acumulada do pulsar universal. Ao mesmo tempo que o seu narrador se preparava para abandonar a biblioteca onde diariamente se afogava em pergaminhos e papéis, M. de Carvalho tomava a pena para construir uma metamorfose tão do

5 Este é um motivo literário tratado de uma forma sugestiva e insistente, por exemplo, nos diversos contos que constituem a colectânea A inaudita guerra da Avenida Gago Coutinho (1992), Lisboa, Caminho, reimpr. ${ }^{9} 2006$ (veja-se, em particular, In excelsum, Ignotus Deus, Dies irae). 
seu gosto e para que criou uma inconfundível estratégia de imagens: aquela que lhe permite produzir a transformação de Realidade em História.

Partiu o viajante de avião, consumando um primeiro exercício de distanciamento: levantar os pés do solo, suspender-se no vazio, para deixar correr, sob os seus olhos, "o giro da terra" (p. 22) ${ }^{6}$. Perdidos os contactos físicos, o autor inicia o processo do apagar de uma realidade para se refugiar no neutro. Uma nuvem imensa que tudo cerca produz um primeiro efeito de desmontagem do espaço, "em que perderam sentido o cima e o baixo". Em simultâneo, o espírito oculta-se sob o véu do sono, trazendo à neutralização do espaço um sugestivo anacronismo, a anulação do tempo (p. 23): "Como quando alguém adormece, sendo muito novo, ao colo de uma velha avó, vestida de preto e de mãos ásperas, enquanto suave lavra o lume na lareira". Esbateram-se as cores, reduziram-se as luzes, silenciaram-se os sons e tudo se confundiu, como uma velha fotografia, numa "residual água-tinta de ténue verde-azeitona recobrindo todas as cores vivas". Para tudo culminar na "molificação" do avião, a diluição definitiva de uma realidade concreta a permitir o salto para o desconhecido.

Desconhecido que o não é totalmente, porque assenta em traves reconhecíveis, de uma natureza não livresca, que a fantasia ou, se quisermos, o mito, de há séculos vêm estruturando. É neste contexto que a palavra "Tebas" se impõe para designar " $a$ Pátria", a remissão última para um primeiro marco de civilização. Quebrado o vínculo com a realidade imediata, o primeiro arrimo a que o ousado viajante lança mão é o da palavra, insistente, obsessiva, veículo de uma ideia que lhe baila no espírito (p. 36): "Uma palavra, Tebas entoa-me o cérebro, repetida, Tebas, repetida, repetida, Tebas". Do cérebro, a ideia como que salta para o papel (p. 36): "Nem sei porquê, lancei em grandes letras nesta folha de papel o nome de uma cidade antiga: Tebas". Abeira-se o momento da criação literária, ideia e palavra associadas como por um impulso que escapa à vontade do criador, uma imposição mais forte, até então insuspeitada. $\mathrm{O}$ itinerário imenso da História e do Tempo ganhou um nome, arrancado ao inconsciente, arquivo de uma memória algum dia colhida. Tebas tem o poder anacrónico e universal de um símbolo, eleito por um acaso de entre outros possíveis; nem Tróia, nem Micenas, Atenas ou Argos; Tebas.

6 Uma expressão paralela encontra-se em Fantasia para dois Coronéis e uma Piscina ( 32004$)$ Lisboa, Caminho, 34, onde M. de Carvalho atribui ao que aqui chama "avião" a designação feliz de "cronovelema", o "navio do Tempo": "Nós vamo-nos afastando, desliza Portugal, verdeja-nos por baixo, ora se afunda, e distinguimos lá ao largo a nítida orla do mar". Num texto onde se propõe "viajar" pela realidade portuguesa, utiliza estratégia comum à que, em O livro grande de Tebas, lhe proporciona "um voo" sobre a realidade universal. 
Atrás do nome, sobrevém um esboço de formas, primeiro indistinto, depois progressivamente consciencializado em linhas mais precisas. Trata-se do difícil exercício de regressar ao tempo antes do concreto, de erguer, como um padrão, a cidade de Tebas, que se vislumbra entre o autor e o papel, que "subvoa" (p. 24) e paira nos ares. A criação aparece como um processo de suspensão, uma cumplicidade que se produz algures, num progressivo reconhecimento, entre o criador e o seu objecto. Se este é a História, prima pela fluidez, faz-se de memória e de futuro, é eterno na sua atemporalidade - "a história passada e futura de Tebas, desmemoriada ou inatingida de seus moradores", p. 39. Parte de um registo, retido nos documentos que se amontoam em bibliotecas e arquivos, incapazes por si de captar o pulsar das realidades que os ditaram. No seu convencionalismo nada contam, são meras enumerações, inventários de contas que não retratam a verdadeira vida, excluídos "factos, acontecimentos, movimentos, impulsos, sentimentos, um rasgo de gente". Postos de lado os testemunhos, não de todo inúteis mas em si mesmos insuficientes, de que outros materiais dispõe o criador para repor os traços de uma verdade total e convincente? De um outro amontoado, não de mil e mil páginas, amareladas pelo tempo, mas de uma multiplicação igualmente incontável de gestos, cada vez mais, com o passar dos anos, esbatidos, anónimos e frouxos, desfalcados de vitalidade e sentido. Haverá limites para este relato da memória, inspirado num eterno afrouxamento?

Pensar Tebas torna-se então ainda mais difícil. Além de um corte exigido com a realidade imediata que coarcta a criatividade e a imaginação, pensar Tebas é também o erguer de fronteiras, o interpor, no curso da História, de uma barragem, de modo a distinguir o antes e o depois. A ideia de passado começa no justo ponto onde se escreveu a palavra "último": de Tebas, a última flecha, a última porta, a última tenda, a derradeira ronda (p. 40). Vem então "o nevoeiro", a capa diluidora que cobre o tempo concreto, que, no seu imenso poder, mesmo se lento, subreptício - "baixinho, baixo, forte, alto" -, é impositivo, torna "sons" em "ecos", e um lugar definido em "vastíssima planura" sem contornos. Ao claro e real sucede-se o anónimo e o obscuro, massas informes, engrenagens e esferas, numa espécie de regresso ao caos primitivo. Do que foi civilização restam lamas, magmas, pedras e metais, uma espécie de amontoado, informe e em potência, dos elementos à altura da criação. A que poder obedece esta desconstrução não se sabe. Mas após a sua intervenção, resiste apenas a memória ou o sonho de uma realidade conhecida; e, para o espírito humano, o enigma: "Passar além das engrenagens, devassar uma outra esfera, não creio que homem passe, e adregue contá-lo". 
Ultrapassar limites insuperáveis, desafiar o logos, na sua duplicidade dialéctica e retórica, é esta a máxima odisseia a desafiar o Homem.

Erguer Tebas tem de começar pela criação da "ideia", ainda geral, de cidade. Por isso, um primeiro passo funciona como a colecção de "materiais" que inevitavelmente se associam ao conceito. A terminologia urbanística domina num primeiro esboço (p. 24): "Terraços, arcarias e praças e esplanadas, ruas estreitas e largas, agulhas de catedral, lances de zigurate (...), a massa do casario", filtrados por uma cortina opaca de nevoeiro, são como que um catálogo anacrónico e, por isso, universal, da imagem que qualquer ser humano, independentemente da sua origem ou cultura, tem de "cidade". Tão impressionista quanto a própria imagem, a enumeração implica os traços genéricos de um paradigma: a dimensão ampla (expressa pela insistência no superlativo: "cidade imensíssima", "a maior cidade do mundo, a mais desconhecida dele"), a tonalidade arcaica que remete para um passado longínquo ("rocha cinza irregular toscamente lavrada"), o sentido de memória histórica que obedece à regra da continuidade ("lembra", "permanece, rolando lenta, lenta, com o tempo"). O leitor atento não deixará de registar o vazio humano, no que é por enquanto, partindo do caos primitivo, um simples jogo de formas. Para o narrador tratou-se de preparar uma Tebas em potência, a partir da "massa" essencial de que se constrói qualquer cidade.

Reunidos materiais, o passo seguinte implica a selecção, de entre os elementos básicos, daqueles que podem convir à criação de uma Tebas determinada, "a minha Tebas” (p. 32). Está dado o primeiro passo para uma actualização do arquétipo. Uma certa ordem de convenções convive com uma nova disciplina, de modo a que a tradição seja conscientemente assimilada. Como falar ou imaginar uma Tebas sem portas nem muralhas, na estrita obediência a um padrão que a Antiguidade consagrou?? Como não poderia deixar de ser, "a minha Tebas" tem "cem torres e mil portas", acompanhando no exagero dos números a vastidão da paisagem em que a vemos implantada. Com a definição de um traçado mais nítido, a cidade imaginada passa a integrar vida e acção humana, aquela que melhor convém à mesma referência tradicional (p. 32): "Anoto que há homens e que uma batalha qualquer ali se fere". Deixamos a amálgama de rochas toscas e de cinzas, para vislumbrar uma geografia humana. Da rendição que esta etapa representa por referência ao mito, dá M. de Carvalho testemunho: "Aceito Tebas, todos os seus recônditos".

7 Naturalmente que textos como Sete contra Tebas de Ésquilo ou Fenícias de Eurípides, dedicados à dramatização do mito tebano, surgem como remissão inevitável para a arquitectura desta outra Tebas. 
A consciência de que uma tradição lhe subjaz leva o autor a ponderar sobre modelos. Que evocações irrompem da palavra "Tebas"? Adiamos por um momento o projecto de uma recriação ou reescrita, para promover a revisão das Tebas de referência, com os seus atributos específicos. Pela negativa - "não será decerto a Tebas do Velho Egipto", "não é tampouco a Tebas erigida ao rés de montes agudos e pedrosos" -, as Tebas da tradição são elencadas, como contributos determinantes na construção de uma lenda. Talvez a alusão ao "Velho Egipto" dê, à Tebas faraónica, a preferência, por antiguidade. Mas, mais do que os anos, são os traços específicos que lhe conferem identidade. Com "Tebas" competem, neste caso para maior precisão, nomes alternativos - "On, Tebas Luksor, Tebas Carnak" -, associados a uma localização agora exacta, "não longe do Vale dos Reis". São espirituais as suas primeiras insígnias, "os sacerdotes de Ámon" que, com os seus "cantos eternos", a fazem ressoar. As construções que a definem são as que convêm ao Egipto, casas cúbicas de adobe, fundidas sob uma tonalidade incontornável, "rósea e amarélea do sol". Domina-a, também ele marcado pela cor, "o braço moreno do faraó", um dos muitos que, durante quatro milénios, conduziu a força do Egipto, à frente de "legiões e legiões e legiões". A Tebas ideal ganhou, por estes traços, uma identidade própria: sem deixar de ser bélica - ou não fosse ela Tebas -, passou a só fazer sentido em terras do Nilo.

Por essa mesma individualidade, a egípcia se opõe a outra Tebas famosa, erigida numa paisagem não menos característica, aquela em que as pedras que cobrem montes altaneiros se entrecruzam com "nesgas cintilantes de mar turquesa ao fundo". Esta é, certamente, a Tebas grega, nas faldas do Citéron, "cintada de granitos muros que evocam Antígona e Creonte e Édipo e a Esfinge e Píndaro e Alexandre" e todas as trágicas glórias que testemunhou. A paisagem é diferente, coberta de oliveiras, rodeada de pastagens, mas cenário, também ela, de prolongadas e penosas guerras. $\mathrm{O}$ próprio combate ganha, neste caso, uma natureza "homérica", a que Ésquilo e Eurípides deram eco. É possível desenhá-la, com escudos e o bronze das espadas, com gritos e súplicas de jovens, dados em sacrifício aos altares das divindades. Como não perceber, na generalidade do desenho, a evocação das vítimas da Esfinge e a grandeza de um jovem, Meneceu, filho de Creonte, que, para salvar Tebas da destruição, se imola em sacrifício voluntário, quando o fulgor das armas se comprimia em redor das muralhas da cidade ${ }^{8}$ ?

8 Das tradições aqui aludidas dão testemunho textos como o Rei Édipo de Sófocles ou Fenícias de Eurípides. No primeiro mantém-se viva a tradição de um monstro devorador 
Em concorrência com as duas Tebas da tradição, uma africana e uma europeia, ao autor de O livro grande de Tebas é permitida a "invenção" de uma outra Tebas, asiática desta vez, implantada "no país de Sumer", a que acrescenta, sobre os traços de sempre, a magia oriental. Continua muralhada, prossegue como palco de cruzamento de multidões, mas tem um acabamento exterior que lhe é exclusivo. Vibram nela, como emblema ímpar, "grifos de esmalte brilhante luzindo azuis em tijoleira vermelha, fiadas sem fim de três muralhas direitas", como reflexo de uma fulgurante Babilónia, Susa ou Ecbátana. As multidões que a cruzam, "de barbados encaracolados homens de negócios", colhidas de um quadro de prosperidade e fortuna, fazem alarde das riquezas incontáveis do Oriente, "passeando empenachados nos seus carros floridos pelas avenidas processionais". É uma outra Tebas inexistente, mas fácil de inventar dentro de linhas que a tradição atesta.

A todas estas Tebas do passado M. de Carvalho sobrepõe, num movimento de ring composition, "a sua Tebas", para ele "concreta, ainda que inventada", que obtém pelo desmontar e reconstruir sucessivo do mito (p. 34): "Nem tem sete nem cem portas, assinaladas pela lenda (...) Tem cem torres e mil portas que poderia contar e descrever, deambulando-lhe em torno das muralhas, numa vastíssima extensão". Esta é a Tebas entrevista do avião, a cidade do nowhere, da utopia, que foge a qualquer "território conhecido dos velhos compêndios". Situa-se em extremos nunca percorridos, isentos da marca de pegadas, "muito para lá das nuvens mais altas". Caracteriza-se pelo "não ser", como negativo das suas iguais nos traços que lhes são comuns: "Tebas em espessa bruma escondida, nem fria nem quente, nem seca nem húmida, tem cem torres altas, pesadas, escuras e quadradas, tem mil portas pequenas e gradas, esguias e largas, e vai cercada há muitos mil anos, por infindas legiões de silentes, serenos, solenes guerreiros". É uma verdadeira imagem mítica, oculta sob o manto da fantasia, traçada num desenho único, construído por antinomias e sussurrado em hábeis aliterações.

Feita a opção por um modelo, cabe ao autor satisfazer uma ânsia íntima e natural: a de tocar a sua Tebas, de a conhecer (pp. 104-105), de lhe palpar os vestígios e de a percorrer pela memória. Porque embora livre na sua

às portas de Tebas, a Esfinge, de que Édipo libertou a cidade (cf. S. Rei Édipo 35-39, 390398, 507-510); em Fenícias (944-952, 963 sqq.), trata-se com minúcia o tema do sacrifício voluntário de Meneceu, em nome da salvação da cidade. Por fim, o confronto dos dois filhos de Édipo - Etéocles e Polinices - e dos exércitos sob seu comando, pela posse do trono de Tebas, justifica a imagem da cidade invadida que serve de cenário à referida peça de Eurípides e a Sete contra Tebas de Ésquilo. 
criação, ele continua escravo de uma imagem, onde testemunho livresco e tradição incorpórea se aliam.

Como promover esse contacto, antes de mais físico, com uma Tebas ideal? Sem dúvida pela visita, pela proximidade concreta, sentir e ver Tebas com mãos e olhos, "se viajantes lá houvera" (pp. 51-52). Como em todas as visitas aos vestígios do passado, seriam os monumentos, "os três maiores da cidade", a concentrar a atenção; e porque relevantes marcos da memória, é junto deles que "a névoa é mais compacta". Seria este o tipo de projecto que um arqueólogo, o visitante natural do passado, seguiria, na peugada do que é esperável num campo de ruínas. Dos monumentos-padrão de uma Tebas para além das nuvens, a descrição só pode ser simbólica. Falta-lhes nitidez, tendem para uma forma redonda, regular, indistinta ("outro monumento é uma esfera colossal", "o terceiro é um enorme globo de granito"), a que estranhos acessórios se ajustaram ("de que emergem mil tubos (...) uns grossos como troncos, outros da finura de agulhas", "perfurado de mil orifícios, todos de desigual diâmetro, uns anchos, por onde cabe tronco de homem, outros finos da finura de cabelos"). Distingue-os uma variedade contraditória de elementos, numa espécie de amálgama de todas as possibilidades; o primeiro é mesmo dessa mistura o paradigma por excelência: "Um dos monumentos é um gigantesco poliedro irregular, de mil faces, e aspecto sempre diverso, revelado no circunvagar da bruma". A grandeza, associada ao emaranhado de linhas, torna-os únicos e inacessíveis a recuperar uma configuração exacta.

Será talvez de introduzir um ponto de ordem neste projecto de viajar pela História, para reconhecer que há, na cidade ideal, alvos diversos a privilegiar. Instala-se então uma dúvida metodológica (pp. 104-105), expressa em sucessivas interrogações, sobre o plano a seguir para percorrer não só os seus três maiores monumentos, mas tudo o que constituiu a sua existência plena. "As tuas torres e os teus exércitos" são a ponta do fio, o primeiro passo da visita, ou não é por eles que a vida em Tebas ganha sentido? A etapa seguinte implica insuflar, na legenda de fundo, um conteúdo. "Torres", como referências de defesa ou de ataque, trazem a menção de máquinas e cabos, enquanto "exércitos" impõem figuras circulantes e "repetidos, amiudados gestos, dos exércitos cercados, do exército de sítio". Num plano sucessivamente mais cerrado, o ângulo de perspectiva fecha-se progressivamente sobre "muros e casarios", como sobre homens com uma existência que vai para além dos simples exercícios do combate. Há famílias em Tebas, as torres escondem as casas, a guerra oculta um outro quotidiano. Mesmo a mole anónima do exército se humaniza com a imagem pessoal de "três silentes soldados que 
armam a balista, lhe fixam o pelouro, soltam a alavanca, olham, faces paradas, o desfechar do engenho". Homens e máquinas ganham um corpo, movem cada fibra, exibem uma face, ainda que sem ruído e sem pressa, como se vivos e maleáveis sob o nevoeiro bloqueador do Tempo. Tebas, porém, prepara ainda uma surpresa. Não é só o exterior dos atacantes, por contraste com o interior dos defensores, o que constitui os dois planos da sua existência. Intramuros, nos limites mais profundos da sua physis, há outra dicotomia: entre o plano íntimo das suas entranhas, onde se penetra a custo, abertas galerias, para um encontro inesperado com "os pequenos monstros sáurios que de olhos em brasa fitam", num regresso ao momento da sua fundação; por contraste com o da sua vida, onde "salões, claustros, praças, câmaras, corredores, escadarias, janelas, fontanários, frontões, portas, corredores, colunas", outrora barulhentos e banhados de luz, se quedam agora obscuros e silenciosos.

A penumbra da História começa por cobrir (pp. 85-86, 91-92) toda a cidade onde a sucessão alternante do dia e da noite se quebrou, vítima do próprio desgaste. A luz, ainda que escassa, a envolver a memória não vem do sol; nem sombras há, o que pressupunha o reflexo dos raios do astro-rei. Dessa luz difusa sobressaem não mais do que "volumes, formas e contornos, figuras e feições", numa harmonia essencial entre "a natureza das pedras e da bruma", vestígios e memória aliados contra a escuridão de um esquecimento que tudo apague. Também para a "bruma" qualquer explicação científica é inútil. Às interrogações que suscita - "e que bruma é esta?”, p. 91 -, que são uma tentativa de perceber a História, não responde a descrição de um fenómeno físico; não se trata de um vapor proveniente de evaporação, porque não há, em volta dessa Tebas que paira nas alturas, qualquer curso de água que a justifique. Nem tão pouco partículas de pó, porque não é arenoso o terreno que lhe cinta as muralhas. Logo, "com todas as reservas de uma primeira explicação" (p. 92), há que reconhecer para esta bruma uma outra causa, a que a funde com as próprias pedras, Tempo e Obscuridade como duas circunstâncias indissociáveis. Sobre pedras, gentes e guerreiros, esta névoa funciona de moldura, que cerca uma tela e lhe estabelece os limites; porque em volta de Tebas nada há, ela existe por si mesma nos seus contornos brumosos.

Este é, em linhas gerais, o retrato de uma Tebas que M. de Carvalho passa a construir em pormenor. Em primeiro lugar, Tebas será sempre uma cidade cercada, envolta em aparatoso arsenal de guerra, povoada de sitiantes e sitiados. Fazer-lhe o desenho, como se de uma pintura da História se tratasse, é imobilizá-la, na suspensão e no silêncio. Mas atentemos agora no particular. Sobre as muralhas alinham-se, "pensativos", os defensores de Tebas, a observar 
a massa do inimigo que ameaça. $\mathrm{O}$ texto português regressa ao modelo literário da teichoskopia - ou "observação do cimo das muralhas" - que, desde Homero e com eco patente em Eurípides, se tornou tradicional. Porque se trata apenas de uma descrição inconsequente nos resultados - "grupos de arqueiros, nas ameias, tomam flechas de grandes cestos de vimes, prendem-nas entre os dedos, ajustam-nas à crina tensa, vergam o arco com esforço e apontam, calculando com vagar a trajectória do dardo", p. 39 - os gestos têm de ser precisos, plásticos mas nunca consumados. Literatura e pintura confluem como duas modalidades de mimesis, no retomar implícito de uma velha teoria ${ }^{10}$.

Mas a vigilância de Tebas produz-se também de forma mais recatada, mais íntima, nas tendas que servem de abrigo à guarda (pp. 120-121). Mais do que avistarem o campo inimigo, aí os homens controlam "entradas e saídas". Quando o visitante se concentra sobre o sentido dessas tendas surge a interrogação: "Quem habita as tendas redondas ali plantadas aquando do primordial assédio da Tebas cinzenta?" Ninguém parece existir no que não passa de um "cenário de vigilância", mais um elemento indispensável num contexto de guerra. $\mathrm{O}$ mesmo vazio dá asas à imaginação e permite vislumbrar não o que existe, mas o que lá poderia ter existido: um espaço para a ponderação de tácticas militares, um armazém de equipamentos, uma acomodação de guerreiros, vivos ou mortos, ou simples portas de saída para além de Tebas, que a um só tempo marcam e desfazem limites. São como um ponto / umbigo do mundo, ao mesmo tempo um local preciso, fixo, mas de onde se parte através de um olhar lançado sobre o além ${ }^{11}$. Será este olhar um simples gesto de vigia, que a guerra exige, ou um efectivo "olhar além", daqueles que procuram penetrar, mais do que a realidade imediata, o verdadeiro desconhecido e o sentido pleno de tudo o que os desafia?

9 Cf. Ilíada 3. 166-242, em que Helena aponta a Príamo, do cimo das muralhas de Tróia, os guerreiros destacados do exército grego; e Eurípides, Fenícias 88-195, em que, acompanhada pelo Pedagogo, Antígona, sobre os muros de Tebas, olha o exército argivo, que se aliou a seu irmão Polinices na reivindicação do seu direito ao trono paterno. Sobre este tema e sua execução literária, vide Silva, M. F. (2005), Ensaios sobre Eurípides. Lisboa, Cotovia: 288-289, 293-300.

10 Cf. Aristóteles, Poética $1447^{\text {a }} 18-23,1448$ b 4-19.

11 Como o vigia famoso que Ésquilo, Agamémnon 1 sqq., plantou sobre o telhado do palácio de Micenas, numa longa espera de um sinal que anunciasse o destino do seu senhor e seus homens, partidos à conquista de Tróia, também M. de Carvalho recria "o guerreiro, sentado ao alto de uma fraga, ( ), pernas pendendo, vestidas de grevas, figura meio curvada, de costas voltadas a Tebas", p. 122. Ao serviço da casa onde se imobiliza, mas de certa forma ausente dela, todo o impulso do seu olhar escrutina o desconhecido. 
Não menos expressiva de um subtexto inspirador, que encontra nos já citados Homero, Ésquilo e Eurípides uma fonte irrecusável, é a "descrição do guerreiro", com os seus trajos e armas convencionais ${ }^{12}$. Mais do que concretizar ou particularizar, este é um elemento que, paradoxalmente, irmana atacantes e defensores. Em pouco diferem os agentes da guerra, são, acima de tudo, "combatentes". Pertencem-lhes, por isso, elmos, túnicas, saios, lorigas, escudos, arcos e flechas, sandálias ou borzeguins, que, numa evidente mistura de sabor anacrónico, confluem no fluxo ininterrupto da História da guerra. Sobrepõem-se-lhes os eternos emblemas decorativos ("em todos os elmos, e em grande diversidade, há incrustações várias de trabalhos retorcidos que representam flores e frutos e plantas, entrelaçados com grande engenho"; "no couro, foram gravados motivos geométricos, em fiadas já meio-sumidas e nunca com cor, em que o triângulo é figura prevalente, mas também o semicírculo e o trapézio", p. 56), de onde é patente a mescla de motivos, desde os que se inspiram numa natureza vigorosa - e alheia à destruição da guerra -, até ao neutro primitivo das formas geométricas. Também eles contribuem para a noção de "sem tempo", que associa a elaboração de traços retorcidos com a limpidez de esquemas elementares. E, num aprofundar voluntário do anacronismo que reina numa viagem pelo Tempo, o narrador cria, com a evocação do tradicional, um choque de contemporaneidade. De um sírio sem idade (pp. 56-57), a quem interroga sobre a ideia que faz de Tebas, a de Tirésias, obtém a mais inusitada das respostas: "Tebas? É lá em cima, na Grécia. Agora tem caminho-de-ferro, um entroncamento. Faz-se muito comércio". O metal que antes enchia a Tebas guerreira de estranhos brilhos sobrevive nos caminhos do progresso e da modernidade, carris e comboios penetrando a cidade noutro tempo.

$\mathrm{Na}$ sua policromia, os guerreiros que povoam as colinas em volta de Tebas constituem um todo retalhado em batalhões, que nos devolvem ao modelo de um tradicional catálogo ${ }^{13}$. Reunindo as diversas tradições, $\mathrm{M}$. de Carvalho reparte-se entre a imagem das tropas em repouso ou activas na

12 Sobre esta tradição na épica e na tragédia grega, aplicada aos paradigmas de Tróia e Tebas, vide Silva 2005: 343-368 e bibliografia aí citada.

13 Ilíada 2. 484-760, a par de outras ocorrências significativas no mesmo poema (4. 223-241, 771 sqq., 816 sqq., 16. 168 sqq.), é deste modelo épico um exemplo famoso, na descrição que faz das tropas sitiantes e sitiadas na guerra de Tróia; Eurípides, no párodo de Ifigénia em Áulide (164-302), regressa ao motivo com uma plasticidade impressionante, desenhando o exército grego, em repouso, na expectativa da partida para Tróia. Sobre a matéria, vide Silva 2005: 344-350; Beye, C. R. (1964), "Homeric battle narrative and catalogues", HSCh 68: 345-373. 
preparação do combate (pp. 67-68). Os homens diluídos na massa, fixos, parados, são a anónima maioria; enquanto as actividades próprias de um exército são executadas, em simétrico anonimato, em grupo. Aos primeiros caracteriza-os a força de um insistente "não" ("não patrulha, não move máquinas de guerra, não investe as muralhas, não roja projécteis"), aos segundos a dinâmica do gesto ("aprestam ... pousam ... fincam ... cortam ... retiram ... apontam ... desferem"). São, no total, uma mole imensa, com competências definidas: há archeiros, besteiros, infantes, cavaleiros. Percebe-se-lhes os movimentos, sinal de uma previsível arremetida; tudo se passa, porém, numa penumbra por trás da qual o número e a acção se diluem e as cores se desbotam, dominada por um silêncio, que abafou qualquer "pequenino som de retinir ou zumbido, ou sopro".

Da massa anónima, qualquer esforço para nomear um chefe seria vão (pp. 48-49). Os nomes de referência, ao comando da luta fratricida de que a Tebas mítica foi cenário - Etéocles e Polinices, os filhos de Édipo, diante de garbosos companheiros -, sumiram-se; a hierarquia do comando perdeu sentido, apagou-se tal como a nitidez de linhas e sons. Cada ordem obedece apenas a um modelo pré-estabelecido - "a ninguém obedecem os militares de Tebas, porque ordens nunca são proferidas, antes pré-ordenados estarão desde os primórdios os gestos de batalha”. Do mito de referência, a efemeridade da memória não consente mais do que um anonimato geral, sem menção dos seus actores inevitáveis.

Depois da uniformização de atacantes e atacados, o combate ordena-se, na sua imperiosa dicotomia, em volta de um símbolo forte: as portas de Tebas. É nelas que se concentra o ataque, substituída uma visão abrangente por um alvo concreto. Os golpes que a tradição salvaguardou, no entanto, não deixam na robustez aparente "dos batentes chapeados" marca concreta, apesar do vigor agressivo das armas de investida, "pesadíssimos aríetes cabeça de carneiro de altos troncos petrificados", e da violência dos golpes "a dar e dar (...) desde há muitos mil mil anos para cá" (pp. 77-78). Na sua fragilidade alada, são as palavras que perduram, livres de repetirem os vestígios de uma lenda que, essa sim, se não apaga. De sete portas e dos seus sete atacantes se cresce para cem, um número que amplia a tradição. Ésquilo, nos Sete contra Tebas, pintou este episódio, onde os escudos são um elemento central de memória ${ }^{14}$. Presentes ainda nesta outra versão, os

14 É célebre o longo episódio dos "sete pares de discursos", em Sete 375-684, em que Etéocles é levado, pela descrição dos sete atacantes de Tebas, e em particular dos escudos 
escudos são apenas de "enodoado vime", sem a decoração que lhes dava voz e fazia deles intérpretes do sentido das vontades em confronto.

Se Ésquilo pode ser uma remissão para a simbologia dos escudos no desenho literário da guerra, é-o também para o retrato de uma população desarmada sob a fúria dos combates, os simples "habitantes de Tebas" (pp. 39-40). Partilham do imobilismo e do silêncio que os rodeia, vivem numa anarquia colectiva arquivada pelo Tempo. São "mansos nos gestos", monótonos nos movimentos, "vão e vêm, e passam e perpassam em sossego, ou em sossego ficam, naquele seu apagado modo de estar de branda população sem tino". Exprimem-se em gestos ritmados, obedecem à simultaneidade coreográfica de um coro de tragédia. Falta sentido, projecto, objectivo à sua vida. Parecem autómatos, subservientes a uma força superior. Um flash valoriza uma componente precisa, as mulheres, carpideiras sem prantos nem bramidos. São aquelas Tebanas que Ésquilo moveu, como um coro impressionante, no ambiente de conflito que é o dos Sete. São as mesmas que um dia se confrontaram com um ímpeto militar, que introduziram nas ordens de combate prantos de aflição, atentas aos ruídos que, vindos do exterior, anunciavam a presença inimiga e o fim iminente da sua segurança. À distância do Tempo elas são apenas vultos sem som, que evocam, mesmo assim, horas fatais no destino da cidade.

Quase estulto seria procurar ainda em Tebas um sinal de vida, partir da guerra, sua insígnia natural, à procura dos dias felizes. Talvez viciado pela monotonia em que fora criado, antes de se atrever à louca aventura de a abandonar, o narrador, mergulhado nas brumas de Tebas, empreende também a busca da sua rotina. É emblemático o espaço onde a recupera; no coração da cidade, onde o clamor da guerra mal chega, está o estádio, símbolo máximo da existência colectiva, robusto na altura dos seus muros, lisos no exterior, mas a esconderem, dentro, uma bancada de pedra - capaz de oferecer ao cidadão acolhimento, não o da intimidade das casas, mas o do convívio social. Trata-se de uma espécie de cidade dentro da cidade. "Um espigão alto", a spina, divide em duas a pista; mas mais do que ordenar o espaço do certame, onde carros, gladiadores e feras um dia fizeram vibrar

que carregam, símbolo da personalidade e motivações de cada um dos seus possuidores, a montar a estratégia mais adequada à defesa da cidade. Com esta cena, Ésquilo revela ao seu público o significado profundo de um combate, cujo desfecho é evidente mesmo antes do começo. 
multidões, essa coluna é, no momento, o marco da História, erguido para identificar o lugar e permitir a reconstituição do que se apagou.

Enquanto tacteia as pedras e percorre, com passo cauteloso, a insegurança do terreno, o visitante reproduz, em imaginação, as horas de glória de que o estádio é feito. Basta-lhe reconstituir um único dos cidadãos de Tebas ali sentado, "no sétimo degrau da quarta bancada", cotovelos nos joelhos, cabeça entre as mãos espalmadas. Estende o olhar ao longe, até à tribuna de honra onde se instalariam os juízes, simples olhar imaginado, mas que dá nobreza e majestade ao recinto.

Esta imaterialidade, que faz de tudo em Tebas uma realidade abstracta, causa mal-estar no visitante, aquele que a penetra como se materialmente não existisse, sem deixar rasto. Apesar do seu empenho em se aproximar, será sempre o intruso, "estranho àquelas terras, àquelas gentes e àquela guerra tão sem tempo" (p. 94). Se é verdade que as portas da cidade se lhe franquearam espontaneamente e lhe permitiram o percurso de tudo o que protegiam, é também certo que a sua passagem não ficou "nunca registada na memória", como que cativa de um geral anonimato. A História é afinal caminho aberto, sem portas nem barreiras, mas brumoso, arriscado e impenetrável.

De uma visão de Tebas à superfície, M. de Carvalho convida-nos a um olhar mais penetrante sobre as profundezas que se escondem, só acessíveis por "corredores intermináveis (...) que se prolongam pelo ventre da terra e não acabam em parte nenhuma" (p. 90). Somos levados para além dos contornos nevoentos de uma Tebas construída, à procura dos tempos, mais remotos ainda, da sua origem. No âmago da terra, sobrevivem os "monstros", não já o dragão que o mito fixara como guardião de um solo virgem onde Cadmo, guiado por mão divina, quis implantar os alicerces da civilização ${ }^{15}$; lá reinam, no "sem tempo" do romance, "animais escamosos e gordos, de frio sangue, hirtos, inteiriços, único movimento pressentido a respiração de bafo gelado, olham fixamente com os seus olhos parados" (p. 90; cf. p. 38). Impregna-os ainda um sabor mágico, na "lucífera cor" que emitem, saída das esmeraldas, rubis e rosáceas que os recamam. São estas as cores únicas que resistem em Tebas,

15 Esta é a explicação mitológica para justificar o sangue vertido num terreno, na hora em que à barbárie se substituía a civilização. Mas do dragão eliminado, nas suas mais remotas origens, resultou para a Tebas mítica uma maldição, que só o sangue dos seus filhos poderia redimir. $\mathrm{O}$ destino anunciado para Tebas exprimia-se por uma violência, fatal e duradoira. Cf. Ésquilo, Sete contra Tebas 69-75; Eurípides, Fenícias 638-675, 931-941. É curiosa a vaga correspondência entre Fenícias 660, na menção "às pupilas vigilantes" do dragão, e o desenho vistoso que M. de Carvalho aprofunda do motivo. 
as que registam, em tons fulgurantes, a sua origem. Este é, para o "viandeiro da hipótese" - a persistente curiosidade humana -, "o limite da afoiteza possível"; "deterá sua marcha tacteante ao pressentir esses seres primordiais (...) e se volverá logo à bruma dos ares, inquietado por dentro, triste da sua impotência de passar além". Com a descida ao âmago da terra e das suas origens, o homem atingiu as franjas da própria imaginação. Defrontou-se aí com o absoluto, viu-se diante da fronteira que o separa, como ser efémero, do conhecimento oculto no infinito (p. 90): "A imensa sageza contida em tais olhares fê-lo pequenino e desencorajou-o de aprofundar a marcha".

Erguida, em pensamento, a sua Tebas, importa ao autor assumir o papel de um velho escriba do Egipto e ser capaz de introduzir, no fluxo do registo histórico ou da ficção literária, o seu testemunho (pp. 127-133). Porque, ao lado da História, existe essa outra cadeia eterna da palavra que lhe dá expressão. Entre as duas é necessária compatibilidade, para que a harmonia seja efectiva. E uma pergunta mais se perfila neste longo questionário sobre Tempo e História: a que soube o texto, que consultamos à distância, aos seus contemporâneos? Uma verdade fica clara: a do sentir, em cada época diverso, de cantos, fórmulas e rituais. Perante esta certeza, resta a dificuldade de, pela literatura, fazer vibrar emoções a propósito de uma remota Tebas; enorme é o desafio de arrancar das brumas do passado vibrações convincentes e actuantes.

Que durabilidade têm os gestos dos guerreiros ou os quadros de guerra? Que relação temporal separa a guerra ao vivo da sua imagem, traçada pela História? $\mathrm{Ou}$, mais obscuro ainda, como recuar aos dias, puramente lendários, que assistiram à fundação de Tebas e em que a cidade viveu a alegria da paz e da pujança, embora erigida sobre um lastro de sangue a condicionar-lhe o destino?

Estas são perguntas que denunciam a incontornável precaridade humana, e aquela necessidade que rende o Homem à busca de um princípio e de um fim para tudo o que o rodeia. A finitude humana é avessa à noção de eternidade, não dispensa a ideia do antes e do depois.

Por essa mesma natureza se pode apor, sobre as perplexidades quanto à origem e passado de Tebas, igual questão sobre o seu futuro. Até quando poderá perdurar, neste inevitável empalidecimento de uma realidade, o sentido de História? 